\title{
BIBLIOGRAPHY OF SHORT TITLES
}

Alexander, Peter. A Shakespeare Primer. London, 1951.

Allen, T. W. Homer: The Origins and Transmission. Oxford, 1924.

Bassett, S. E. The Poetry of Homer. Sather Lectures XV, 1938.

Beaujon, Edmond. Acte et passion du héros. Genève, 1948.

Butcher, S. H. Aristotle's Theory of Poetry and Fine Art. $2 \mathrm{~d}$ ed., London, 1898.

Bywater, Ingram. Aristotle on the Art of Poetry. Oxford, 1909.

Calhoun, G. M., in The American fournal of Philology, LXI (1940) 257-278.

Carpenter, Rhys. Folk Tale, Fiction, and Saga in the Homeric Epics. Sather Lectures $\mathrm{XX}, \mathrm{I} 946$.

Collingwood, R. G. The Idea of History. Oxford, 1946. The Principles of Art. Oxford, 1938.

Cornford, F. M. The Republic of Plato, translated. Oxford University Press, I94I.

- Thucydides Mythistoricus. London, I 907.

Finley, J. H. Thucydides. Harvard University Press, 1942.

Fyfe, Hamilton. Aristotle: The Poetics. Loeb Classical Library, 1927.

Glover, T. R. Herodotus. Sather Lectures III, 1924.

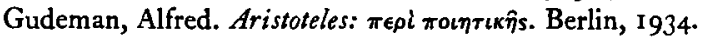

Laistner, M. L. W. The Greater Roman Historians. Sather Lectures XXI, 1947.

Mackay, L. A. The Wrath of Homer. University of Toronto Press, 1947.

Monro, D. B. Homer: Iliad. Oxford, Igo6.

Owen, E. T. The Story of the Iliad. Toronto, 1947.

Parry, Milman, in Transactions of the American Philological Association, LIX (1928) 235-247, and Harvard Studies in Classical Philology, XLI (1930) $73^{-147}$, XLIII (1932) $1-47$.

Ross, W. D. Aristotle. London, 1923.

Scott, J. A. The Unity of Homer. Sather Lectures I, 192I.

Sheppard, J. T. The Pattern of the Iliad. London, I922.

Stanford, W. B. The Odyssey of Homer. 2 vols., London, $1947^{-1948 . ~}$

Thibaudet, Albert. La Campagne avec Thucydide. Paris, I 922.

Twining, Thomas. Aristotle's Treatise on Poetry, translated. London, 1789.

Tyrwhitt, Thomas. Aristotelis de Poetica liber. Oxford, 1794.

Vahlen, Johannes. Beiträge zu Aristoteles Poetik. Vienna, I 865-1867.

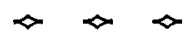

In addition to the foregoing I should name three books which are scarcely referred to in the following chapters, to which, nevertheless, I owe much: Paul Mazon's Introduction al'Iliade (Paris, 1943), H. D. F. Kitto's Greek Tragedy, 2d ed. (London, 1950), and Jacqueline de Romilly's Thucydide et l'imperialisme athénien (Paris, 1947). H. T. WadeGery's book, The Poet of the Iliad (Cambridge University Press, 1952), did not appear till after my manuscript had been sent to press, or I would have taken much from it. 